\title{
PROFESSIONAL SELF-DEVELOPMENT OF A TEACHER OF A HIGHER EDUCATION INSTITUTION: INTERDISCIPLINARY ASPECT
}

\author{
OLESIA SMOLINSKA, KHRYSTYNA DZYUBYNSKA
}

\begin{abstract}
This article deals with the urgent problem of teacher's professional self-development at a higher educational institution, based on normative and acmeological aspects. In the process of achieving this goal - which is the study of the peculiarities of professional self-development in the terms of Ukrainian higher education in its cultural and historical context - the analysis of such problems, as the transformation of forms of consciousness into educational interactions; professional archetype of a teacher; the transformation of the content of professional selfdevelopment, was conducted. The given problem has practical meaning. It means that there are a number of objective factors, which influence the essence of a teacher's professional selfdevelopment, as a process, connected with the concept of lifelong education, and turn it into a component of the creation of professional identity.

We came to the following conclusions: firstly, concerning the dual nature of professional and personal identity (real and imaginary, virtual), which is objectified in the cultural and educational space of the university; secondly, studying the peculiarities of the teacher's self-development, special attention should be paid to appropriate archetypes as culturally conditioned generalized patterns; thirdly, a change in the type of teacher's professional self-development is caused by both the transformation of the character of the person's identity and the change of archetype.
\end{abstract}

Keywords: professional self-development, teacher, identity, archetype, higher education.

\section{INTRODUCTION}

The problem of teacher's professional self-development in the Ukrainian realities is much more complicated than it may seem at first superficial sight, due to which it is possible to reveal its normative, deontological and acmeological preconditions.

The actualization of the problem of professional self-development is first of all facilitated by the concept of continuing education, lifelong learning as a general approach to all professions, which is reflected particularly in the branch Concept of development of continuous pedagogical education [6] . "The order of professional development of pedagogical and scientific-pedagogical workers" [15] in section 2 it obliges teachers to improve their professional skills. In the next section (p. 3), the content of professional development is clarified, in addition to professional competencies, it is necessary to perform additional tasks and duties, as well as digital, managerial, communication, media, inclusive speech and other competencies. Among the types of advanced training, in addition to training 
according to appropriate programs, internship and participation in seminars, workshops, trainings, self-education and other activities "that were conducted beyond the educational establishment's advanced training plan" are also allowed. Thus, the professional self-development of Ukrainian teachers has already received regulatory support.

The next, and not less significant, step in enhancing the value of professional self-development, not only as a self-initiated activity of a certain individual, but also it is an attempt to relate teachers' selfdevelopment work to the level of his or her income. In particular, there is a discussion about the rejection the tariff grid for teachers and the formation of transparent approaches to evaluating the results of their work instead, including achievements in self-development [1]. Self-education, which is in logical unity with informal education, and is recognized as one of the possible kinds of education [7, art. 8, paragraphs. 4, 5], gets to the same level as the formal one, so its results can have impact both on the quality of life of a particular specialist and on the quality of his professional activity, as well as on the quality of education both within the internal system and a system as a whole.

The acmeological content of the problem of professional self-development of a teacher consists not only in the continuous work on oneself as a way to achieve higher levels of professionalism, but also as a universal approach to increasing the level of professionalism in all the spheres.

\section{ANALYSIS AND DisCUSSION}

Despite the number of prerequisites, which have already been formed, self-education (selfdevelopment) of Ukrainian teacher remains additional, secondary to the main, actually teaching, activity. This is due to the fact that some specific Ukrainian problems have not been solved yet, so the purpose of this article will be to research them as well as to find ways to overcome them.

Therefore, we consider that there are the following key issues concerning of teacher's professional self-development:

1. transformation of forms of consciousness in educational interactions;

2. change of professional archetype of teacher;

3. transformation of the content of professional self-development.

\subsection{TRANSFORMATION OF FORMS OF CONSCIOUSNESS IN EDUCATIONAL INTERACTIONS}

The problem of changing forms of consciousness in educational interactions is interdisciplinary. Consciousness is a category both philosophical and psychological, at the same time, it is difficult to overestimate its importance in pedagogy, in particular - higher education $[2 ; 11]$

Forms of consciousness, such as science, religion, law, morality, and others are undergoing significant changes that is the result of the introduction of the fifth technological stage [8]. Its duration, as well as others, is determined by the theory of K-cycles (K-waves) M. Kondratieva [4], according to which the phase of fluctuation of economic indicators changes every 50 (with a deviation of 10) years. Thus, the fifth technological stage has continued since 1980. It is characterized by the predominance of information, telecommunication technologies, micro- and optical-fiber technologies, the development of artificial intelligence and biotechnologies. The end of the large cycle, which is lasting now, is accompanied by a phase of decline. It arises because of the retard of social changes from technological and economic demands and results in crisis and depressive phenomena and difficulties that predetermine the necessity of changes.

Hence, objectively changes of the forms of consciousness can be justified by a change of the technological stage (C. Perez [8]) and wave theory (M. Kondratiev [4]). From the philosophical point of view, U. Sevastianiv deals with the way of the transformation of forms of consciousness with regard to the forms of religiosity. Analyzing the phenomenon of virtuality, the researcher emphasizes a Baudrillard approach, among others, according to which "..." a virtual illusion "... strives for cloning itself, and then for destruction of the reality by its double" [10, p. 70-71], which, accordingly, leads to the crisis of identity in the aspect of the problem of consciousness (self-consciousness). Moreover, U. Sevastianiv also defines a Deleuze approach, due to which the existence of an original and a copy at the 
same time: "There is no more choice [selection possible] between real and unreal, between true and false" [Quotation 10, p. 68]. Thus, the author concludes, "since we cannot get rid of them in modern conditions, it is necessary to admit their existence and learn to co-exist with them" [10, p. 69]. This thesis is closely interrelated with N. Scotna approach [13], according to which a person feels different influences in a split civilization, his or her value orientations (including the professional sphere) are formed and developed in a situation of constant difficult choice, while consciousness and actions are constantly corrected because of complex objective and subjective circumstances. In this regard, $\mathrm{N}$. Scotna says that self-determination act is an act, which acquires characteristics of moral choice and becomes culturally significant.

Thereby, consciousness (self-consciousness), professional and personal identity, forms of their manifestation in modern education (especially higher) are poly-conditioned, so they lose their integrity, have a dual character (real and imaginary at the same time). There is much criticism now both in relation to higher education institutions and teachers, students on the occasion that higher education is becoming a simulacrum, however, based on the above, it can be considered as an evidence of the existence of the original, namely higher education in Ukraine and the performance of its subjects.

Another result of the above made analysis is that both teaching and learning as activities dramatically change their character from linear activity (even poly-motivated) into a methodological, represented by a number of mutually agreed decisions of the subjects of educational activity. One of such decisions is the decision of teacher's professional self-development as the way to ensure the professional development and the projection of future professional development of a modern student. Ultimately, the teacher's professional self-development as reality is virtualized and later is objectified in the cultural and educational space of higher educational institution [14], as a conscious choice of the environment made by a student for his or her self-development. Conversations with high school entrants and their parents show an increasing interest in scientific schools that exist at universities and it is obviously one of the effects of the objectification, which was described above.

\subsection{The Change of Professional Archetype of a Teacher: Search Models}

In order to compare the quality of content transformation and form of teacher's professional selfdevelopment, a fixed professional "image" should be chosen. The examples could be taken from internal systemic background (the best teachers, contest winners, historical personalities among teachers, founders of leading pedagogical / scientific schools, etc.). The temporal factor may be contradictory to this model category, because they can be either contemporaries or not, so as a result, the comparison will be complicated by the separation of the time influence from the professional system itself. Concerning contemporaries, the charisma of a particular person can possibly have influence, which may cause the biased choice of a specimen for comparison, for the purpose to imitate.

The collective image of a teacher from abroad can be a standard model for comparison. Currently this model is actively promoted through internships, distance courses, TED conferences: Ideas worth spreading conferences [16], and lecturers from abroad. However, in order to determine, and moreover, to compare changes in the content and form of professional self-development of a common Ukrainian teacher of higher educational institution, such standards are aimed at the future, so, apparently, they are more suitable for prognostication than for clarifying the essence of changes that have already happened or should happen in the nearest future.

Another contrasting model, which is specific to Ukrainian realities, is the type of Soviet teacher of a higher educational institution. It is also rather heterogeneous image, as the processes in the formation of universities that took place in the previous period (mid 90s - early 2000s) transformed the former institutes and academies into universities, whereas the teaching staff remained the same, often lacking the experience of university teaching, without understanding the universal essence of science and university pedagogy. In fact, the existence of the latter is still a matter of debate both on the level of personal conversations (one of conversations took place between one of the authors of this article $\mathrm{O}$. Smolinska and Professor O. Vyshnevskyi) and in scientific discourse. 
For better understanding of this theme, we consider it appropriate to compare the stylistics of professional self-development of Ukrainian and Soviet teacher as, firstly, this type of a teacher preceded the modern one on our terrains, and, secondly, he was a mentor of the modern generation of Ukrainian teachers.

In this connection, in order to avoid concretization and therefore subjectivization, it is appropriate to refer to the comparison of archetypes as culturally stipulated generalized models [5].

\subsection{TRANSFormation OF THE CONTENT AND Form OF THE TEACHER'S PROFESSIONAL SElF- DEVELOPMENT}

There were many attempts to classify teachers in the psychology of higher education: according to the style of decision-making, according to the type of communication, according to the process or result orientation, etc. There were also attempts to compile "professional portraits" within the surveys framework "Teacher through the eyes of the student" [3; 9]. They combined not only the elements of evaluation, but also planned the promotion of "desirable" and overcoming "undesirable" features. Particularly these researches were actively conducted during the period of numerous transformations of institutes, academies into universities. Obviously, it was caused by the crisis of identification, the search of the new content of the professional competence of the teacher. Nowadays, such studies are less popular because the search of identity has shifted to the level of institutions: universities have to specify their own image, find out the value system.

Returning to the problem of self-development: a standard Soviet teacher had clear parameters of professional self-improvement, they included appropriate programs for improvement, its frequency, forms of reporting, and documents. All these elements are still present in the system of formal (institutionalized) professional development. The expansion of forms that was mentioned above includes short-term training and single educational actions, as well as the combination of scientific and pedagogical professional development through internships. The internal mobility of teachers should be added, as it will soon become much more active and may also be characterized as a form of professional development.

However, the need for the implementation of "additional functions" and the formation of metaprofessional competencies (communicative, digital and others) also causes significant changes in the type of personality. If only a typical Soviet teacher with a scientific degree had the right to change $30 \%$ of the content of the lecture (from the experience of conversations with the older generation of teachers - author.)! The modern educator defines it independently, considering the content of the program, which is also often personally compiled, focusing on educational and/or professional standards (if they are available). Thus, the teacher uses his own professional, scientific and pedagogical experience, the quality of which depends directly on the efforts put into his self-development.

The next parameter is scientific work, the thematic choice of which was clearly regulated during the Soviet period and did not comprise the component of individual scientific interest. Modern extremely rapid growth of the amount of scientific information is due to the influence of the factor of scientific interest.

Therefore, the two main areas of professional development are more or less retaining their form, although their content is changing.

However, the professionalism of a modern teacher also includes: the knowledge of foreign languages, information and communication technologies skills, ability to inspire, leadership abilities, communicative competence, stress resistance, emotional intelligence, ability to recognize and overcome the effects of professional burnout, etc. All of these characteristics can be formed only in the process of self-development as purposeful, consistent and systematic work of the person himself. These needs could be partially met at the expense of the university's internal resources, namely: organized courses, trainings, workshops, engaging teachers in arts activities, promoting and encouraging the development of their physical culture, holding events aimed at the formation of organizational culture. A special role should be given to the work of the social-psychological service and trade union. In spite of a formal 
self-government and autonomy, both universities and teachers, accordingly, are dependent on vertical power decisions. It means that the archetype of the Soviet teacher, dependent on the will of the "higher" authorities, is still vital and it is a significant obstacle for the formation of individual selfdevelopment programs.

Social and philosophical aspect, which is equally significant in the professional self-development of the modern Ukrainian teacher is the weakness of his own (and at the university level) sense of dignity, consequently - low social responsibility, inability to widen professional vision and problems with professional identification. It results in the decline of the authority of a teacher, and the intensification of attacks on the profession as a whole and its representatives in particular. In this regard, one of the pathologically inadequate defensive responses, that are clearly demonstrated, is self-discredit in order to minimize harm from an external attack. T. Shevchenko in his lines: "Good, brother. But who, then, are you? "_"We don't know - Let the German speak! "- clearly reflects the blurring of identity and further uncertainty in self-educational actions:

And so you read Kollar, too,
With all your might and main,
Safarik as well, and Hanka,
Full-tilt you push away
Into the Slavophils, all tongues
Of the Slavonic race
You know full well, but of your own
Nothing! "There'll come a day
When we can parley in our own
When the German teaches,
And, what is more, our history
Explains to us and preaches,
Then we will set about it all!" [12]

Finding effective ways of protection against communicative attacks, as well as ways of strengthening own social positions remains the subject of self-improvement.

At present a model image of the modern Ukrainian teacher is still characterized by uncertainty about the leading features, narrow professional competence is stimulated, best specialist is considered to be either the most effective scientist, or the best producer, a teacher or another (administrator, organizer, compiler of educational and methodical documentation, etc.). Accordingly, the purpose of the self-improvement program is deformed; its key component is lost: that is focusing on the professional needs of a particular personality.

\section{CONCLUSIONS}

To sum up, the problem of professional self-improvement of a modern teacher at higher educational institution is complex and interdisciplinary. It comprises philosophical, psychological, legal, ethical, economic, social and other aspects, which were partially described in the article. Its solution is not easy or instantaneous to find because it is not a homogeneous or even a professional group united by common interests. The professional self-development of a teacher should follow the same direction as the development of the cultural and educational space of a particular institution of higher education, in such a way it will contribute to improving the quality of education, the implementation of strategic tasks, and the development of the professional community. Moreover, purposeful educational policy should be one of the conditions of the teacher's professional selfdevelopment as well as clear requirements to the teacher; another one is assertion of his dignity, increase of the authority of the profession, leveling of professional simulacrum and the limitation of amateurism. 
The prospect of the research consists in the study of the teachers' self-educational intentions, development of personally oriented programs of their professional self-development, clarifying the content of the necessary psychological and pedagogical support.

\section{REFERENCES}

[1] Conceptual principles for reforming public funding and management of higher education institutions. MES of Ukraine, (2019). Available at: https://drive.google.com/file/d/1obC0K1NMhh9soat7LK9yughV4n070-h/view?fbclid=IwAR1ja1JCy-et3kS583r3x9NkYW1FM85B3KNE6pqZeL2hPRmjgnKttZbxKA. (in Ukrainian)

[2] Furman A.V. Metatheoretical mosaic of consciousness life. Psychology and Society, 3-4 (2018). 13-50. Doi: 10.35774/pis2018.03.013 (in Ukrainian)

[3] Hapon N., Dubniak M. The teacher through the eyes of students. Bulletin of the Lviv University. Pedagogy Series, 25 (1) (2009), 106-113. (in Ukrainian)

[4] Kondratiev N.D., Yakovets Y.V., Abalkin L.I. Big business cycles and foresight theory. Selected Works. Economics, Moscow, 2002. (in Russian)

[5] Kravchenko A. Teacher archetype: idea, image, responsibility. Liga-Press, Lviv, 2013. (in Ukrainian)

[6] On Approval of the Sectoral Concept of Continuing Teacher Education Development. Order of MES of Ukraine, 1176 (2013). Available at: https://zakon.rada.gov.ua/rada/show/v1176729-13 (in Ukrainian)

[7] On education. Law of Ukraine, 2145-VIII (2017). Available at: https://zakon.rada.gov.ua/laws/show/214519 (in Ukrainian)

[8] Perez C. Technological revolutions and Financial Capital: The Dynamics of Bubbles and Golden Ages. Edward Elgar Publishing, Northampton, MA, USA, 2002.

[9] Rozhanska N. The idea of an ideal teacher of students of the Black Sea State University named after Petro Mohyla. Scientific works. Sociology, 222 (234) (2014), 80-83. Available at: http://irbisnbuv.gov.ua/cgi-

bin/irbis_nbuv/cgiirbis_64.exe?C21COM=2\&I21DBN=UJRN\&P21DBN=UJRN\&IMAGE_FILE_DOWNL OAD=1\&Image_file_name=PDF/Npchdusoc_2014_234_222_18.pdf (in Ukrainian)

[10] Sevastianiv U.P. Virtual reality as a factor of transformation of the religiosity forms of a modern man. Dissertation for the degree of Candidate of the Religious Studies: 09.00.11. Available at: http://eprints.zu.edu.ua/30373/1/dys_Sevastianiv.pdf (in Ukrainian)

[11] Shandor F. The notion of consciousness in contemporary philosophical discourse. Higher Education of Ukraine, 2 (2011), 73-79. Available at: http://nbuv.gov.ua/UJRN/vou_2011_2_14 (in Ukrainian)

[12] Shevchenko T. To my fellow countrymen in Ukraine and not in Ukraine living dead and as yet unborn. Available at: https://taras-shevchenko.storinka.org/to-my-fellow-countrymen-in-ukraine-and-not-inukraine-living-dead-and-as-yet-unborn-my-friendly-epistle-poem-of-taras-shevchenko-ukrainian-toenglish-translation-by-vera-rich.html

[13] Skotna N.V. Person in a split civilization: education, worldview, actions. Ukrayinski tekhnologii, Lviv, 2005. (in Ukrainian)

[14] Smolinska O. Ye. Theoretical and methodological foundations of cultural and educational space of Pedagogical Universities in Ukraine. University book, Sumy, 2014. (in Ukrainian)

[15] Some issues of professional development of pedagogical and scientific-pedagogical workers. Resolution of the Cabinet of Ministers of Ukraine, 800 (2019). Available at: https://zakon.rada.gov.ua/laws/show/8002019-п (in Ukrainian)

[16] TED: Ideas worth spreading. Available at: https://www.ted.com/

Address: Olesia Smolinska, Khrystyna Dzyubynska, Stepan Gzhytskyi National University of Veterinary Medicine and Biotechnologies, 50, Pekarska Str., Lviv, 79010, Ukraine. 
E-mail: smolinskao@gmail.com, dzyubynskakhr@gmail.com

Received: 15.12.2019; revised: 14.02.2020.

Смолінська Олеся, Дзюбинська Христина. Професійний саморозвиток викладача закладу вищої освіти: міждисциплінарний аспект. Журнал Прикарпатського університету імені Василя Стефаника, 7 (1) (2020), 41-47.

У статті розглянута актуальна проблема професійного саморозвитку викладача закладу вищої освіти на основі врахування нормативних та акмеологічних аспектів. В ході досягнення поставленої мети - дослідження особливостей професійного саморозвитку в умовах української вищої освіти в ії культурно-історичному контексті - проведено аналіз таких проблем, як: перетворення форм свідомості в освітніх взаємодіях; архетип викладача-професіонала; трансформація змісту професійного саморозвитку. Окреслена проблема має практичний зміст. Він полягає в тому, що існує низка об'єктивних чинників, які впливають на сутність професійного саморозвитку викладача як процес, співзвучний концепції неперервної освіти, перетворюють його на скдадник творення професійної ідентичності. Однією 3 форм професійного саморозвитку науково-педагогічних працівників визнано мобільність, завдяки чому вдосконалюеться знання іноземних мов, навички володіння інформаційно-комунікаційними технологіями, комунікативна компетентність, емоційний інтелект, здатність розпізнавати та долати наслідки професійного вигорання і т.п. Всі ці характеристики можуть формуватися дише в процесі саморозвитку як цілеспрямована, послідовна і систематична робота самої людини задля підвищення професійної майстерності.

Основними висновками автори вважають: по-перше, подвійний характер професійноособистісної ідентичності (реальний та уявний, віртуальний), що об'єктивується в культурноосвітньому просторі університету; по-друге, у дослідженні особливостей саморозвитку викладача варто ураховувати відповідні архетипи як культурообумовлені узагальнені взірці; по-трете, зміна типу професійного саморозвитку викладача обумовлена як перетворенням характеру ідентичності особистості, так і зміною архетипу.

Кдючові слова: професійний саморозвиток, педагог, ідентичність, архетип, вища освіта. 